\title{
The Changing Secondary Market
}

\section{Gordon Wood}

The Secondary Market for LDC debt does not operate in the same way as a stockmarket for a number of reasons. The most notable difference is the basically illiquid nature of the Secondary Market. Although the total amount of value impaired sovereign debt exceeds $\$ 1000$ bn, only a tiny fraction of this can be considered as tradeable at any time. The reason for this is simply that most banks cannot afford the losses which they would incur by selling for cash. A rough weighted average price for $\mathrm{LDC}$ debt would be about 30 per cent of face value; in order to sell without loss, a bank would require provisions of over 70 per cent, and very few have achieved this level. Those who have, tend to heave a sigh of relief and drop the paper into the bottom drawer; they are happy to collect the interest income, which naturally looks high in relation to assets on the books at perhaps one third of face value, or even less.

The second major difference from a stock market is the motivation of the buyers of the debt. Generally speaking, the debt is not purchased by people who expect the price to go up. There is an increasing element of speculative activity by brokers in the market but usually in small amounts on a short term basis, because taking positions in a volatile, illiquid market is highly dangerous. There are two basic types of buyers: firstly, investors, either local or foreign, who require the paper for conversion into local currency to make investments or cancel indebtedness; and, secondly, banks which are conducting swap transactions - obviously having sold something they (or an intermediary) have to buy something to complete the swap.

The above characteristics must be borne in mind when considering whether, and to what extent, various factors will affect the market. One perhaps surprising feature is that economic or political events in LDCs, positive or negative, have much less impact on the market, at least in the short run, than might be imagined. This observation may be explained as follows: potential sellers of debt are constrained not by optimism about the prospects of repayment, but by their inability to absorb losses; potential buyers tend to be looking for cheap investment opportunities. For example, over the past year Yugoslavia's domestic economic condition has deteriorated, with inflation rising to over 1000 per cent; however, the price of the debt has risen from 42 to 56 over this period because of the existence of a debt conversion programme. Similarly the price of Chilean debt has been more closely linked to the existence of, and changes to, the country's debt-equity programme than to the economic fundamentals.

The market is affected, negatively, by actions which may impose pain on lenders. For example, a suspension of interest payments lasting for more than a few weeks obliges the banks to admit that these loans are value impaired. The cost of funding nonperforming assets, coupled with pressure from regulators, may induce banks to sell for cash or swap into relatively more attractive countries. A demand for new money will have a similar effect.

Certainly the market has been affected by increasing levels of provisions made by lenders. Provisions enhance the ability of banks to take losses. Unfortunately, the market tends to anticipate such action and prices promptly fall to below the latest average provisioning levels

At the risk of some over-simplification, the dynamics of the secondary market may be said to represent a balance between: 1) the supply of debt available from banks willing and/or able to take the losses and 2) the demand arising from official or informal debt conversion programmes. Given the enormous potential supply, it is not surprising that prices have tended to fall. It should be noted that the existence of a debtequity programme in for example Chile does much more than create demand for Chilean debt Intermediaries will naturally try to fulfil orders for debt by buying for cash but if willing sellers are not available at acceptable prices (which will be the case more often than not) they will try to induce banks to swap out of Chile into, perhaps, Mexico in return for a fee. The intermediary will then have to buy Mexican debt, creating demand for the latter. The market may be perceived as a bath-tap with the tap on and the plug out; cash sellers pour various types of debt into the pool where it is swapped and swirled about, eventually to flow out and be cancelled by debt conversions.

\section{The Effect of Debt Reduction Plans on the Market}

Until very recently debt relief would have had a 
disastrous effect on the world's financial system, wiping out the net worth of many large banks. Even now it will prove distinctly uncomfortable for banks with inadequate provisions, such as those in Japan and Italy. Elsewhere, there is a growing acknowledgement of the judgement of the market, i.e. that these loans are worth much less than their face value. There is no reason to suppose that such debt relief in itself will have basic direct effects on the way the market operates. It will simply introduce a new reason for indulging in swap transactions.

It is noticeable that despite the fanfare surrounding the Mexican agreement, Mexico's debt has fallen from 44 to 36 over the past few months (admittedly a period of falling prices in general). The fundamental point about debt forgiveness is that it forces lenders to take losses. Banks unable to do so have to swap out of countries such as Mexico and into others deemed less likely to follow suit.

Only 100 per cent debt forgiveness would have (obviously) a major impact on the market and that is not on the table except for a few African countries which can never hope to service their debts and which were never actively traded in the first place. However, the Mexican Plan and its possible successors are expected to have indirect effects on the secondary market, and these are discussed below.

\section{Possible Futures for the Market}

The first possibility which we may call the wishful thinking scenario from the creditors' point of view is that, one after another, countries will enter into rescheduling agreements with their creditors perhaps with an element of debt reduction; pursue the economic policies required to service their debts and pay them off over, perhaps, 20 years. If creditors were to believe that this was likely, sales at a discount would diminish sharply, investors looking for yield would bid prices up to par and the market would disappear. As I earn my living as a trader of the debt you will not be surprised to hear that in my opinion this scenario is the least likely of all. However, I can advance solid reasons for this opinion. The domestic sacrifices required over many years are in most cases simply too great for governments to demand and expect to maintain political stability. How many regimes could impose the internal discipline which enabled Romania to repay its debt?

You may say that under this scenario debtor countries would once again be perceived as creditworthy and could raise voluntary new money to service existing debts. However, most banks now acknowledge that they allowed cross-border lending to expand beyond prudence. They will take much convincing to re-start lending to countries which have caused problems in the recent past. Romania is now effectively debt-free, but despite its exemplary treatment of its creditors, that country would not find it easy to raise new money. In addition, if the secondary market price of a country's debt is 35 , why pay it back at 100 (or at 65 after an agreed debt reduction programme such as Mexico's)? If the will exists to make at least some effort to repay the debt, countries will prefer to buy back their debt in the secondary market either: a) by encouraging foreign investment and the return of flight capital by allowing debt-equity conversion schemes or b) by direct buy-backs either openly, like Bolivia, or surreptitiously. Some take the view that debt buy-backs at a discount are somehow immoral; they should note that the Bank of England is openly repurchasing the British National Debt at secondary market prices.

Another scenario which puts me out of a job even more rapidly is repudiation. If this happens, the debt obviously becomes worthless. Even in this case, where there is an effective, as opposed to formal, repudiation, the debt continues to trade in the "twilight zone' below 10 per cent of face value. Examples would be Peru, North Korea and Nicaragua. However, the consequences of repudiation are severe: all access to credit is cut off, trade stagnates, and the country's reputation takes years to recover. How much easier to agree a deal with creditors whereby they disburse new money to service the interest on existing debt, and agree to reschedule the principal.

Until recently, the only 'middle way' was the 'Perpetual Rescheduling' scenario. This involved at its simplest sufficient economic adjustment to generate a trade surplus, and a rescheduling of principal every couple of years, probably with an element of new money. This process ensured a flow of business for the secondary market as banks would sell for cash or swap out of countries to avoid calls for new money or another tiresome round of reschedulings. This process seems unlikely to continue. As banks increase their provisions they become progressively less willing to disburse new money; they have sufficient provisions to absorb losses if they have to, and are naturally reluctant to disburse new money which is then subject to an immediate write-down.

The current trend towards economic reform in return for partial debt forgiveness seems likely to prolong the life of the secondary market and to affect it in various ways. Firstly most of these new packages will include, at the insistance of the banks, debt-equity conversion options. These create demand for debt and generate fee income for creditors and intermediaries. They help to sustain activity in the market. Secondly, we may expect to see a proliferation of debt instruments. The Mexican Plan, for example, will, if successful, generate two new types of bond and a new money loan. This growth in the menu of options 
should enable intermediaries to design swap packages more closely matching the requirements of their customers. The process will be aided by the improved 'tradeability' of the assets. In the early days of the market it was common to encounter Loan Agreements with vague, restrictive, or even completely absent provisions for the assignment of participations. Lenders viewed sovereign borrowers as clients, and often felt that to trade loans would damage relationships.

In practice, the borrowers do not care and lenders these days place little or no value on relationships which have proved to be so expensive. Consequently most new restructuring agreements require no more than a transfer certificate to be sent, after the event, to the agent and/or the borrower. Bonds require even less documentation. This trend will enable the market to process transactions more rapidly and efficiently.

Until recently LDC debt was very obviously being traded in a severe bear market. At current price levels, however, adventurous investors are beginning to think that the yield on certain countries' obligations compensates for the risk. For example an interest yield of over 25 per cent on Mexico may be attractive; even after the new plan is in place, an investor who has purchased the debt for 35 and then opted for the principal discount bonds is still gaining an interest yield of close to 20 per cent. As a rough rule of thu mb, most LDCs could service half their existing debt without difficulty. Consequently an investor purchasing performing LDC loans for well under half price is not likely to show serious losses. Not a play for widows and orphans, but we may expect high yield investors to play an increasing, if still small role in the market.

Despite my opening remarks concerning the ability of banks to take losses, this is also changing as banks increase their provisions. Recently several banks have taken the view that having made large provisions and written down the debt to secondary market levels, they should turn a problem into an opportunity by trading the debt to generate fees. We may expect this process to continue, and this must inevitably increase competition in the market. Life will certainly become more difficult for market players lacking either a portfolio from which to operate or an established niche in the business.

In conclusion, the market seems likely to display the features of a mature market: many players, a wide range of assets, and intensifying competition.

As a final note on the debt crisis, it is worth pointing out to those hailing the Mexican Plan as a blueprint for solving the problem, that, even if they are right, the 'good news' is that the lenders' shareholders may, perhaps, be repaid one-half to two-thirds of the money lent, before allowing for inflation, and over a very long period of time. Hindsight may be a wonderful thing, but in this case the crisis could have been avoided by reference to previous experience.

Countries do go bust and have done so for centuries. The first known debt default is recorded in the Old Testament, when the Israelites were unable to pay the Phoenicians for work done on the Temple of Jerusalem. A later example is perhaps an even better parallel of recent events. At the end of the Middle Ages, the Bardi and Peruzzi were bankers in the world's financial capital, Florence. Fat with profits from loans to domestic industrialists and international traders they were looking for lucrative lending opportunities. They discovered a promising little under-developed country: it was politically stable, had a small population, and was the world's largest exporter of industrial raw materials. It was called England. The bankers lent very large sums to King Edward III, secured on exports of wool. Instead of using the money productively (from a banker's point of view!) he used it to pay for the pursuit of a war against France. Inflation soared as spending exceeded revenues, and Edward was forced to debase the currency. After Edward's victory at the Battle of Crecy, England prospered, but he defaulted on his debts. The Bardi and Peruzzi were ruined. Many similar examples could be cited and the moral is a simple one: sovereign lending has always been a licence to lose money. 